\title{
LPS-Induced Release of IL-1 $\beta$, IL-1Ra, IL-6, and TNF- $\alpha$ in Whole Blood from Patients with Familial Hypercholesterolemia: No Effect of Cholesterol-Lowering Treatment
}

\author{
NATASJA DE BONT, MIHAI G. NETEA, CHANTAL ROVERS, TINEKE SMILDE, ANNEKE HIJMANS, \\ PIERRE N.M. DEMACKER, JOS W.M. VAN DER MEER, and ANTON F.H. STALENHOEF
}

\begin{abstract}

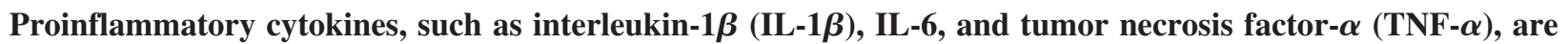
suggested to have an important role in the process of atherosclerosis. Patients with heterozygous familial hypercholesterolemia (FH) have a marked elevation in the plasma level of low-density lipoproteins (LDL), and they show early development of atherosclerosis. The aim of the present study was to test with a whole blood culture system if hyperlipoproteinemia is associated with increased cytokine production capacity in these patients and if treatment with 3-hydroxy-3-methylglutaryl coenzyme A (HMG-CoA) reductase inhibitors influences this production capacity of blood cells, at both the protein and mRNA levels. The capacity of blood cells

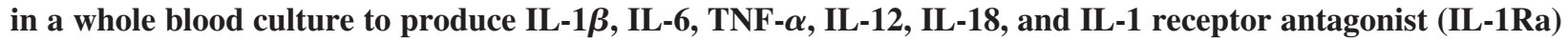
in response to lipopolysaccharide (LPS) appeared to be similar for heterozygous FH patients and healthy volunteers. Furthermore, the capacity to produce IL-1 $\beta$, IL-6, and TNF- $\alpha$ in response to LPS was not modified by cholesterol synthesis inhibitors at the level of mRNA expression or at the level of release. On the other hand, the release of IL-1Ra was significantly increased after treatment with HMG-CoA reductase inhibitors, although only at the protein level. This suggests a possible beneficial anti-inflammatory role for this therapy.
\end{abstract}

\section{INTRODUCTION}

$\mathbf{E}$ NDOTOXIN, THE LIPOPOLYSACCHARIDE (LPS) component of the outer membrane of gram-negative bacteria, is considered to be one of the most important mediators in the pathogenesis of gram-negative sepsis. ${ }^{1}$ In addition, studies suggest a role for LPS-induced immune mechanisms in the development of atherogenesis. ${ }^{2-4}$ Several mechanisms may be responsible for initiation of the atherosclerotic lesion. One such mechanism is the formation of complexes of LPS with the lipoproteins ${ }^{5}$ that are transported from the circulation into the arterial wall, where they initiate an inflammatory response. ${ }^{6}$ In addition, LPS has a macrophage-activating capacity and can induce oxidation of low-density lipoprotein (LDL), ${ }^{7}$ a major mediator in atherogenesis. ${ }^{8,9}$ The expression of adhesion molecules can be upregulated by LPS, causing increased adhesion of monocytes and $\mathrm{T}$ cells to the endothelium. ${ }^{10-12}$ When compared to controls, hypercholesterolemic animals show more severe and persistent endothelial damage in response to LPS. ${ }^{13}$ It is hypothesized that most of these toxic effects of LPS are mediated by such proinflammatory cytokines as tumor necrosis factor- $\alpha$ (TNF- $\alpha)$, interleukin- $1 \alpha$ (IL- $1 \alpha$ ), and IL- $1 \beta$, produced by monocytes and macrophages. ${ }^{1}$ It has been postulated that hypercholesterolemia in combination with LPS may increase the risk of developing atherosclerosis, with LPS causing the initial endothelial damage and hypercholesterolemia disrupting the normal repair process. $^{2}$

Only a few reports deal with cytokine production in hypercholesterolemic hosts. Diet-induced hypercholesterolemia in rabbits and in mice has been demonstrated to cause increased LPS-induced TNF production. ${ }^{14,15}$ In addition, peritoneal mac-

Department of Medicine, Radboud University Medical Center, and Nijmegen University Center for Infectious Diseases, Nijmegen, The Netherlands. 
rophages of $\mathrm{LDL}$ receptor-deficient $\left(\mathrm{LDLR}^{-/-}\right)$mice produced more TNF and IL-1 in response to LPS. ${ }^{16}$ There was a tendency toward increased cytokine production by isolated peripheral blood mononuclear cells (PBMC) of homozygous familial hypercholesterolemia $(\mathrm{FH})$ patients, ${ }^{17}$ and it was demonstrated that the TNF- $\alpha$ production capacity of PBMCs of heterozygous FH patients was increased when stimulated with high LPS concentration. ${ }^{18}$ On the other hand, at more physiologic LPS doses, no differences in TNF- $\alpha$ or IL- $1 \beta$ production between PBMCs of heterozygous $\mathrm{FH}$ patients and controls were found. ${ }^{19}$

3-Hydroxy-3-methylglutaryl coenzyme A (HMG-CoA) reductase inhibitor therapy decreases serum cholesterol levels effectively and reduces cardiovascular morbidity and mortality. ${ }^{20,21}$ Reports investigating the effect of cholesterol synthesis inhibitors on cytokine production capacity in vitro demonstrated an inhibitory effect on the production of several cytokines. Lovastatin inhibits LPS-induced expression of proinflammatory cytokines, such as TNF- $\alpha$, IL- $1 \beta$, and IL- 6 , in rat primary astrocytes, microglia, and macrophages ${ }^{22}$ and the production of IL-6 and IL-8 and monocyte chemotactic protein-1 (MCP-1) by monocytes and human mesangial cells, respectively. ${ }^{23,24}$ However, only a few reports describe in vivo effects exerted by cholesterol-lowering therapy on cytokine production. LeirisaloRepo et al. ${ }^{18}$ have shown that hypocholesterolemic treatment did not alter TNF production by monocytes ex vivo. In accordance with these results, we demonstrated that cholesterol-lowering treatment in FH patients also did not influence the production of IL- $1 \alpha$, IL-1 $\beta$, IL-1 receptor antagonist (IL-1Ra), and IL-6 by PBMCs. ${ }^{19}$

Although isolated cell populations can provide useful data, this is an artificial model compared with a system involving whole blood. In a whole blood culture, the time course of $e x$ vivo production of cytokines after LPS stimulation is comparable to that in healthy volunteers after a single LPS injection, ${ }^{25}$ which stresses the importance of this test. An additional advantage of using a whole blood culture over studies with primary cultures or preisolated cells is the maintenance of physiologic metabolite and drug concentrations.

In the present study, we used a whole blood culture to evaluate the cytokine production capacity of patients with heterozygous FH in response to LPS. The effect of treatment with cholesterol synthesis inhibitors on this capacity at both the protein and mRNA levels was studied as well.

\section{MATERIALS AND METHODS}

\section{Subjects}

Twenty-one heterozygous FH patients and 21 healthy controls (Table 1) participated in the study. The patients were treated with inhibitors of cholesterol synthesis. To exclude a direct interaction of this medication with our assays, cholesterollowering treatment was stopped 2 days before draining blood samples in the first series of experiments. For 12 patients, the controls consisted of family members (siblings and parents), and for the other patients, the controls were age-matched and weight-matched healthy volunteers from hospital personnel. No differences in lipid levels and cytokine production between the group of family members and the group of hospital personnel were found (data not shown). There were no significant differences in age or weight between patients and controls.

In a second series of experiments, another 27 heterozygous, DNA-proven FH patients (12 men and 15 women, age $44.5 \pm 9.7$ years, weight $74.2 \pm 9.3 \mathrm{lbs}$.), who had already participated in a clinical trial, were examined to investigate the direct effects of cholesterol-lowering treatment. These patients stopped hypolipidemic medication 8 weeks before the study. Subsequently, the FH subjects were treated, doubleblind, with either simvastatin (40 mg daily) or atorvastatin ( $80 \mathrm{mg}$ daily). Blood samples were obtained just before and 8 weeks after starting the treatment. None of the patients or controls received immunosuppressive therapy during the course of the study, and they had no systemic illnesses that might have influenced the immune system (e.g., diabetes mellitus, rheumatoid arthritis, malignancy). None of the patients or controls had infections in the 2 weeks before testing, and they were all requested to fast overnight. The study was approved by the local ethical committee, and written informed consent was obtained from all participants before being enrolled in the study.

\section{Serum lipid measurements}

Serum levels of total cholesterol, high-density lipoprotein (HDL)-cholesterol, and triglycerides were determined enzymatically on a Hitachi 747 (Basel, Switzerland) analyzer. ${ }^{26}$ LDL-cholesterol levels were calculated according to the Friedewald method. ${ }^{27}$

Table 1. Characteristics of First Cohort of Heterozygous Familial Hypercholesterolemia (FH) Patients vs. Controls

\begin{tabular}{lccc}
\hline & $F H$ & Controls & p \\
\hline$n$ & 21 & 21 & n.s. $^{\text {a }}$ \\
Male/female & $12 / 9$ & $10 / 11$ & n.s. \\
Age, years & $46.7 \pm 15.8^{\mathrm{b}}$ & $39.6 \pm 15.6$ & n.s. \\
Weight $(\mathrm{kg})$ & $75.7 \pm 13.6$ & $71.3 \pm 9.5$ & n.s. \\
Total cholesterol (mmol/L) & $7.6 \pm 1.6$ & $5.5 \pm 0.9$ & $<0.001$ \\
LDL-cholesterol (mmol/L) & $5.8 \pm 1.6$ & $3.7 \pm 0.9$ & $<0.001$ \\
HDL-cholesterol (mmol/L) & $1.18 \pm 0.35$ & $1.26 \pm 0.20$ & n.s. \\
Triglycerides (mmol/L) & $1.71 \pm 0.91$ & $1.21 \pm 0.54$ & 0.03 \\
\hline
\end{tabular}

${ }^{a}$ ns, not significant.

${ }^{\mathrm{b}}$ Mean \pm S.D. 


\section{Blood samples}

Blood from 1 heterozygous $\mathrm{FH}$ patient and 1 control was drawn at the same time and tested simultaneously. Blood from the group of heterozygous FH patients in the second experiment was drawn just before and 8 weeks after starting hypolipidemic medication. Samples were collected into 2-mL (for ex vivo production) endotoxin-free tubes containing EDTA (Vacutainer Systems, Becton Dickinson, Rutherford, NJ). To study the circulating cytokine concentration, one tube was centrifuged immediately at $2250 \mathrm{~g}$ for $10 \mathrm{~min}$, followed by centrifugation of the plasma at $15,000 \mathrm{~g}$ for $5 \mathrm{~min}$ to remove platelets.

\section{Whole blood stimulation}

Cytokine production was measured using a whole blood culture system as described elsewhere. ${ }^{28}$ Briefly, blood was drawn into two 2-mL tubes containing $24 \mu \mathrm{L}$ EDTA-K $_{3}$ (Vacutainer Systems, Becton and Dickinson). One tube was incubated immediately, and the other tube was incubated after the addition of $50 \mu \mathrm{L}$ LPS (Escherichia coli serotype 055:B5, final concentration $10 \mu \mathrm{g} / \mathrm{mL}$ blood) (Sigma, St. Louis, MO). After 24 $\mathrm{h}$ incubation in a waterbath at $37^{\circ} \mathrm{C}$, the tubes were centrifuged as described. Plasma was used for cytokine protein determination. In the second group of heterozygous patients, the tubes were centrifuged after $4 \mathrm{~h}$ of incubation at $37^{\circ} \mathrm{C}$, as this is the optimal stimulation period for cytokine mRNA measurement. After removing the plasma by centrifugation at $2250 \mathrm{~g}$ for 10 min, aliquots of $500 \mu \mathrm{L}$ cell-pellet were taken, and an equivalent volume of guanidinium-isothiocyanate (GITC), enriched with $7 \mu \mathrm{L} \beta$-mercaptoethanol per $\mathrm{ml}$, was added for isolation of total RNA. ${ }^{29}$

\section{Cytokine measurements}

IL- $1 \beta$, IL-1Ra, and TNF- $\alpha$ concentrations were determined using thoroughly validated radioimmunoassays as described previously. ${ }^{30}$ IL-6 concentrations were determined using a sandwich enzyme immunoassay (Pelikine Compact, CLB, Am- sterdam, The Netherlands), and IL-12 and IL-18 were measured by commercial ELISA kits (R\&D, Abbingdon, U.K.). In order to correct for spontaneous cytokine release, the net production was calculated by subtracting the concentrations without stimulus from those induced by LPS.

\section{mRNA expression}

Total RNA was isolated as described previously. The amount and quality of RNA were determined by spectrophotometry. RTPCR for IL- $1 \beta$, TNF- $\alpha$, and $\beta_{2}$-microglobulin $\left(\beta_{2} \mathrm{~m}\right)$ was performed as described extensively elsewhere. The RT-PCRs for IL$1 \mathrm{Ra}$ and IL-6 were performed similarly ( $30 \mathrm{sec}$ denaturation at $92^{\circ} \mathrm{C}, 30 \mathrm{sec}$ annealing at $55^{\circ} \mathrm{C}$, and $90 \mathrm{sec}$ extension at $72^{\circ} \mathrm{C}$ ). To remain in the linear range of the reaction, 25 and 28 cycles, respectively, were run. The sequences of the PCR primers we used are listed in Table 2. To correct for fluctuations in leukocyte count, IL- $1 \beta$, IL-1Ra, IL- 6 , and TNF- $\alpha$ mRNA concentrations in a sample were expressed as a ratio vs. the amount of mRNA of the housekeeping gene $\beta_{2} \mathrm{~m}$. To correct for spontaneous cytokine mRNA expression, the net production was calculated by subtracting the expression rate without stimulus from the expression rate induced by LPS. To minimize analytic variation, samples before and after 8 weeks of medication were tested in duplicate in the same series of PCRs.

\section{Statistical analysis}

Data are expressed as mean \pm SD. Statistical analysis was performed using a Wilcoxon test for paired or unpaired data. Probability $(p)$ values were calculated on the basis of two-tailed tests. A $p<0.05$ was considered significant.

\section{RESULTS}

\section{Lipid concentrations}

Total plasma cholesterol, LDL-cholesterol, and total triglyceride concentrations were significantly higher in heterozygous

Table 2. Primer Pairs Used for mRNA Amplification

\begin{tabular}{|c|c|c|c|c|}
\hline Primer & Sequence & $\begin{array}{l}\text { Fragment } \\
\text { length }\end{array}$ & $\begin{array}{l}\text { Annealing } \\
\text { temperature }\end{array}$ & Cycles \\
\hline \multicolumn{5}{|l|}{$\beta_{2} \mathrm{~m}$} \\
\hline Sense & 5'-CCAGCAGAGAATGGAAAGTC-3' & 268 & 55 & 26 \\
\hline Antisense & 5'-GATGCTGCTTACATGTCTCG-3' & & & \\
\hline \multicolumn{5}{|l|}{ TFN- $\alpha$} \\
\hline Sense & 5'-ACAAGCCTGTAGCCCATGTT-3' & 427 & 55 & 29 \\
\hline Antisense & 5'-AAAGTAGACCTGCCCAGACT-3' & & & \\
\hline \multicolumn{5}{|c|}{ (2) } \\
\hline Sense & 5'-GGATATGGAGCAACAAGTGG-3' & 263 & 55 & 29 \\
\hline Antisense & 5'-ATGTACCAGTTGGGGAACTG-3' & & & \\
\hline \multicolumn{5}{|c|}{ (2) } \\
\hline Sense & 5'-CTTCTATCTGAGGAACAACC-3' & 158 & 55 & 25 \\
\hline Antisense & 5'-TCATCACCAGACTTGACACA-3' & & & \\
\hline \multicolumn{5}{|c|}{ (2) } \\
\hline Sense & 5'-CACCTCTTCAGAACGAATTG-3' & 314 & 55 & 28 \\
\hline Antisense & 5'-GGATCAGGACTTTTCTACTC-3' & & & \\
\hline
\end{tabular}


Table 3. Characteristics of Second Cohort of Heterozygous FH Patients Before and AFTER Cholesterol-Lowering Treatment

\begin{tabular}{lccc}
\hline Characteristic & Before medication & After medication & p-value \\
\hline$n$ & 27 & 27 & $12 / 15$ \\
Male/female & $12 / 15$ & $44.5 \pm 9.7$ & \\
Age, years & $44.5 \pm 9.7^{\mathrm{a}}$ & $74.2 \pm 9.3$ & $<0.001$ \\
Weight $(\mathrm{kg})$ & $74.2 \pm 9.3$ & $6.60 \pm 1.53$ & $<0.001$ \\
Total cholesterol (mmol/L) & $11.37 \pm 1.8$ & $4.81 \pm 1.50$ & $<0.04$ \\
LDL-cholesterol (mmol/L) & $9.40 \pm 1.75$ & $1.22 \pm 0.3$ & $<0.001$ \\
HDL-cholesterol (mmol/L) & $1.16 \pm 0.31$ & $1.37 \pm 0.67$ & \\
Triglycerides $(\mathrm{mmol} / \mathrm{L})$ & $1.99 \pm 0.92$ & & \\
\hline
\end{tabular}

${ }^{\mathrm{a}}$ Mean \pm S.D.

FH patients vs. controls, whereas no difference in plasma HDLcholesterol was found (Table 1). In the second cohort, total plasma cholesterol, LDL-cholesterol, and triglyceride concentrations were significantly decreased $(42 \%, 49 \%$, and $31 \%$, respectively) after hypocholesterolemic treatment, whereas HDLcholesterol concentrations were slightly, yet significantly, increased (5\%) (Table 3).

\section{Cytokine production}

LPS-stimulated cytokine production capacity ex vivo (mean $\pm \mathrm{SD}$ ) was within the normal range. Circulating concentrations of IL- $1 \beta$, IL-1Ra, IL- 6 , and TNF- $\alpha$ and cytokine production of unstimulated whole blood cultures were very low and did not differ between patients and controls after cholesterol-lowering treatment (data not shown).

To overcome variable neutralization of LPS by lipoproteins, ${ }^{5]}$ cytokine production in the whole blood cultures from FH patients and controls was assessed at an excess LPS concentration of $10 \mu \mathrm{g} / \mathrm{mL}$. To examine the influence of hypercholesterolemia on the cytokine production capacity, production of the proinflammatory cytokines IL- $1 \beta$, IL- 6 , and TNF- $\alpha$ and the anti-inflammatory cytokine IL-1Ra in a whole blood culture was measured. Cytokine production capacity was comparable between the cultures of FH patients and controls (Table 4). As HMG-CoA reductase inhibitors have been shown to decrease cytokine production in vitro, we investigated any difference in the ex vivo cytokine production capacity of heterozygous $\mathrm{FH}$ patients as a result of the hypolipidemic treatment. IL-1Ra concentrations in the whole blood culture 4 $\mathrm{h}$ after LPS administration were slightly, albeit significantly, increased, but production of IL- $1 \beta$, IL- 6 , and TNF- $\alpha$ was similar before treatment and 8 weeks after treatment began (Table 5). IL-12 and IL-18 concentrations, important Th1-type inflammatory mediators in atherosclerosis, were in most patients below the detection limit and not different between groups (data not shown).

\section{Cytokine mRNA expression}

The cytokine level found in the plasma after culturing whole blood is the net concentration obtained after subtracting the uptake of cytokines by the cells from the actual production. For insight into the production of cytokines, we also investigated the effect of HMG-CoA reductase inhibitors on transcription of cytokines. The HMG-CoA reductase inhibitors did not influence the expression of mRNA for IL- $1 \beta$, IL-1Ra, IL- 6 , and TNF- $\alpha$ (Table 6), and the concentrations of IL-12 and IL-18 were below the detection limit.

\section{DISCUSSION}

Proinflammatory cytokines are suggested to have a role in LPS-mediated endothelial damage, ${ }^{1}$ in the uptake of oxidized LDL through increased expression of macrophage scavenger receptors, ${ }^{31}$ and in regulating the plaque stability. ${ }^{32}$ Each of these may be important in the process of atherosclerosis. ${ }^{33} \mathrm{Nev}-$ ertheless, it is important in which compartment the cytokines are produced. In plasma, TNF and IL-1 may induce endothelial cell damage, ${ }^{2}$ whereas cytokines produced in the atherosclerotic plaque can stimulate cell proliferation and migration of smooth muscle cells and macrophages, ${ }^{33}$ and decrease the stability of the plaque. ${ }^{32} \mathrm{We}$ investigated whether the blood cells of patients with $\mathrm{FH}$ have an increased cytokine production capacity in comparison to normocholesterolemic controls, which would reflect the cytokine-mediated endothelial damage.

In the present study, whole blood production capacity for the cytokines IL- $1 \beta$, TNF- $\alpha$, IL-6, and IL-1Ra was similar in heterozygous FH patients and controls, consistent with the results found for PBMCs isolated from these subjects, and stimulated with a lower and more physiologic dose of LPS. ${ }^{17-19}$ However, Leirisalo-Repo et al. ${ }^{18}$ reported that at much higher LPS concentrations, comparable to the concentrations used in our whole blood culture, TNF production by monocytes of heterozygous

Table 4. Production of Cytokines in Whole Blood Culture of Heterozygous FH Patients and Controls after Stimulation With $10 \mu \mathrm{G} / \mathrm{ML}$ LPS FOR $24 \mathrm{H}$

\begin{tabular}{lcc}
\hline & $F H(n g / m L)$ & Controls $(\mathrm{ng} / \mathrm{mL})$ \\
\hline IL-1 $\beta$ & $8.9 \pm 4.9^{\mathrm{a}}$ & $9.6 \pm 3.3$ \\
IL-1RA & $8.8 \pm 1.4$ & $10.0 \pm 2.2$ \\
IL-6 & $24.0 \pm 8.8$ & $21.7 \pm 7.5$ \\
TFN- $\alpha$ & $3.8 \pm 2.0$ & $4.0 \pm 1.9$ \\
\hline
\end{tabular}

${ }^{\mathrm{a}}$ Mean \pm SD. Net production was calculated by subtracting the concentrations without stimulus from the concentrations induced by LPS. 
Table 5. Production of Cytokines in Whole Blood Culture after Stimulation with $10 \mu \mathrm{G} / \mathrm{ML}$ LPS for 4 h Before and During Treatment to Decrease Cholesterol

\begin{tabular}{lcc}
\hline & Before medication $(\mathrm{ng} / \mathrm{mL})$ & After medication $(\mathrm{ng} / \mathrm{mL})$ \\
\hline IL-1 $\beta$ & $7.0 \pm 3.2^{\mathrm{a}}$ & $6.5 \pm 2.3$ \\
IL-1RA & $6.1 \pm 1.3$ & $6.5 \pm 1.6^{*}$ \\
IL-6 & $9.8 \pm 4.8$ & $9.3 \pm 4.6$ \\
TFN- $\alpha$ & $3.1 \pm 1.3$ & $3.3 \pm 2.0$ \\
\hline
\end{tabular}

${ }^{\text {aMean }} \pm \mathrm{SD}$. Net production was calculated by subtracting the concentrations without stimulus from the concentrations induced by LPS.

$* p<0.05$.

FH patients was increased, ${ }^{18}$ in contrast to our observations. In both studies, the medication was stopped $24-48 \mathrm{~h}$ before testing. The differences between these results possibly are dependent on the different methods used: PBMCs vs. whole blood culture, the latter more closely approaching the native environment of blood cells. Several substances present in the circulation, such as hormones, antioxidants, and lipids, will be preserved in a whole blood culture. All these substances may affect the immunologic responses of the cells and, in addition, have interactions with LPS. Moreover, the cell to cell interaction is very important, as the release of cytokines by certain cells can inhibit production by other cells. We cannot exclude, however that in FH patients, a source other than blood cells, such as tissue macrophages, endothelial cells, smooth muscle cells, or liver cells, has increased cytokine production capacity.

Diet-induced hypercholesterolemic rabbits and mice demonstrated increased LPS-induced TNF production as well. ${ }^{14,15}$ It is questionable whether results obtained in rodents can be extrapolated to humans, especially when the hypercholesterolemia is of exogenous instead of endogenous origin. Furthermore, the immunologic response may vary with the type and physical state of the LPS, as demonstrated for LPS-binding protein (LBP) binding capacity, which was different for LPS derived from Salmonella ${ }^{34}$ and LPS derived from E. coli ${ }^{35}$ The dietinduced hypercholesterolemia in rabbits was more profound than the hypercholesterolemia in our group of patients. ${ }^{14}$ Such an extreme hypercholesterolemia in these rabbits might have caused an increased rate of oxidation, rendering them more susceptible to LPS.

HMG-CoA reductase inhibitors are at present the first choice of drugs to decrease elevated levels of plasma cholesterol, as these agents decrease serum cholesterol levels effectively and, moreover, reduce cardiovascular morbidity and mortality. ${ }^{20,21}$ Inhibitors of HMG-CoA reductase reportedly inhibited the production of several cytokines in vitro. ${ }^{22-24}$ Pahan et al. ${ }^{22}$ demonstrated that the LPS-induced expression of TNF- $\alpha$, IL- $1 \beta$, and IL- 6 in rat primary astrocytes, microglia, and macrophages was inhibited by $10 \mu \mathrm{M}$ lovastatin, and others showed that the production of IL- 6 and IL- 8 by THP- 1 cells was suppressed after compactin treatment $(10 \mu \mathrm{M}) .^{23}$ Therefore, we determined whether in vivo administration of these drugs can also inhibit the production of cytokines. Using a whole blood culture, we were not able to confirm these findings; the capacity of blood cells to produce IL- $1 \beta$, IL- 6 , TNF- $\alpha$, IL- 12 , and IL-18 was independent of the treatment, at the level of both protein concentration and mRNA expression.
An important difference in our study was the dose of HMGCoA reductase used in these in vitro studies, which is more than a hundred times higher than the physiologic peak plasma concentration of $0.07 \mu \mathrm{M}$ found in humans. ${ }^{36}$ Furthermore, the methods and the origin of the cells used for assessing cytokine production are not comparable.

On the other hand, our results support the observations that treatment of $\mathrm{FH}$ patients with inhibitors of HMG-CoA reductase does not influence the capacity of their PBMCs to produce proinflammatory cytokines in response to LPS. ${ }^{18,19}$ The results obtained with PBMCs particularly showed the indirect effect of inhibitors of HMG-CoA reductase on cytokine production capacity, as the drug was no longer present in the culture. In addition, our results demonstrate that HMG-CoA reductase inhibitors do not have any direct influence on the capacity of blood cells to produce proinflammatory cytokines. Nevertheless, this does not exclude possible direct effects by HMG-CoA reductase inhibitors on in vivo mechanisms. Although we used a system that closely resembles the in vivo situation, there are still many compartments in vivo that could be triggered by these drugs. Cholesterol synthesis inhibitors act mainly in the liver and the intestine, where they inhibit the activity of the enzyme HMG-CoA reductase by about $90 \% .{ }^{37,38}$

In contrast to the capacity to produce proinflammatory cytokines, blood cells of patients treated with cholesterol synthesis inhibitors can produce significantly more of the antiinflammatory cytokine IL-1Ra. However, the IL-1Ra mRNA expression did not change. Apparently, HMG-CoA reductase inhibitors affect the direct release of this cytokine but not the mRNA expression after $4 \mathrm{~h}$. It may be possible that the effect

TABle 6. MRNA EXPRESSION OF CyTOKINES IN Whole Blood Culture 4 h after LPS Stimulation before and AFter 8 WeEks of Cholesterol-Lowering TreatMENT

\begin{tabular}{lcc}
\hline Ratio $^{\mathrm{a}}$ & Before medication & After medication \\
\hline $\mathrm{IL}-1 \beta / \beta_{2} \mathrm{~m}$ & $2.0 \pm 0.5$ & $1.9 \pm 0.5$ \\
$\mathrm{IL}-1 \mathrm{RA} / \beta_{2} \mathrm{~m}$ & $1.0 \pm 0.2$ & $0.9 \pm 0.2$ \\
$\mathrm{IL}-6 / \beta_{2} \mathrm{~m}$ & $1.6 \pm 0.5$ & $1.6 \pm 0.5$ \\
$\mathrm{TFN}-\alpha / \beta_{2} \mathrm{~m}$ & $1.6 \pm 0.6$ & $1.5 \pm 0.6$ \\
\hline
\end{tabular}

aRatio of cytokine mRNA/mRNA expression of the housekeeping gene $\beta_{2} \mathrm{~m}$. Net mRNA expression was calculated by subtracting the concentrations without stimulus from the concentrations induced by LPS. 
of HMG-CoA reductase inhibitors on the release of this antiinflammatory cytokine may be more important than its effect on proinflammatory cytokines. It has been suggested that IL1 Ra plays a pharmacologic role in inhibiting vascular smooth muscle cell proliferation, possibly by interfering with the autocrine regulatory pathway of IL- $1 .{ }^{39}$ It has been demonstrated that IL-1Ra also inhibits IL- $1 \beta$-induced adhesiveness of human vascular smooth muscle cells for monocytes and neutrophils. ${ }^{10}$ Both these mechanisms are important in the process of atherosclerosis, but it should be noted that the increase in IL-1Ra concentrations was minimal, and its biologic relevance remains to be demonstrated.

\section{ACKNOWLEDGMENTS}

We thank Trees Verver-Jansen, Liesbeth Jacobs, Ineke Verschueren, Marielle Spruytenburg, Raymond Krebbers, and Gerard Pesman for help with the cytokine assays and Til Terburg for helping with collecting the blood.

\section{REFERENCES}

1. Lynn WA, Cohen J. Adjunctive therapy for septic shock: a review of experimental approaches. Clin. Infect. Dis. 1995;20:143-158.

2. Lopes-Virella MF. Interactions between bacterial lipopolysaccharides and serum lipoproteins and their possible role in coronary heart disease. Eur. Heart J. 1993;14(Suppl K):118-124.

3. Saikku P, Leinonen M, Mattila K, Nieminen MS, Huttunen JK, Ekman, M.R. Serological evidence of an association of a novel Chlamydia, TWAR, with chronic coronary heart disease and acute myocardial infarction. Lancet 1988;2:983-986.

4. Sinensky M, Logel J. Inhibition of degradation of 3-hydroxy-3methylglutaryl coenzyme A reductase by mevinolin. J. Biol. Chem. 1983;258:8547-8549.

5. Van-Lenten BJ, Fogelman AM, Haberland ME, Edwards PA. The role of lipoproteins and receptor-mediated endocytosis in the transport of bacterial lipopolysaccharide. Proc. Natl. Acad. Sci. USA 1986;83:2704-2708.

6. Navab M, Hough GP, Van-Lenten BJ, Berliner JA, Fogelman AM. Low-density lipoproteins transfer bacterial lipopolysaccharides across endothelial monolayers in a biologically active form. J. Clin. Invest. 1988;81:601-605.

7. Cathcart MK, McNally AK, Morel DW, Chisolm GM. Superoxide anion participation in human monocyte-mediated oxidation of lowdensity lipoprotein and conversion of low-density lipoprotein to a cytotoxin. J. Immunol. 1989;142:1963-1969.

8. Berliner JA, Haberland ME. The role of oxidized low-density lipoproteins in atherogenesis. Curr. Opin. Lipidol. 1993;4:373-381.

9. Yla-Herttuala S. Macrophages and oxidized low-density lipoproteins in the pathogenesis of atherosclerosis. Ann. Med. 1991;23: 561-567.

10. Wang X, Feuerstein GZ, Gu JL, Lysko PG, Yue TL. Interleukin1 beta induces expression of adhesion molecules in human vascular smooth muscle cells and enhances adhesion of leukocytes to smooth muscle cells. Atherosclerosis 1995;115:89-98.

11. Takahashi M, Ikeda U, Masuyama J, Kitagawa S, Kasahara T, Saito M, Kano S, Shimada K. Involvement of adhesion molecules in human monocyte adhesion to and transmigration through endothelial cells in vitro. Atherosclerosis 1994;108:73-81.

12. Seitz CS, Kleindienst R, Xu Q, Wick G. Coexpression of heatshock protein 60 and intercellular-adhesion molecule-1 is related to increased adhesion of monocytes and T cells to aortic endothelium of rats in response to endotoxin. Lab. Invest. 1996;74:241252.

13. Reidy MA, Bowyer DE. Distortion of endothelial repair. The effect of hypercholesterolaemia on regeneration of aortic endothelium following injury by endotoxin. A scanning electron microscope study. Atherosclerosis 1978;29:459-466.

14. Brito BE, Romano EL, Grunfeld C. Increased lipopolysaccharideinduced tumour necrosis factor levels and death in hypercholesterolaemic rabbits. Clin. Exp. Immunol. 1995;101:357-361.

15. Henninger DD, Gerritsen ME, Granger DN. Low-density lipoprotein receptor knockout mice exhibit exaggerated microvascular responses to inflammatory stimuli. Circ. Res. 1997;81:274-281.

16. Netea MG, Demacker PN, Kullberg BJ, Boerman OC, Verschueren I, Stalenhoef AFH, Van der Meer JWM. Low-density lipoprotein receptor-deficient mice are protected against lethal endotoxemia and severe gram-negative infections. J. Clin. Invest. 1996;97:13661372.

17. Rovers C, Netea MG, de Bont N, Demacker PNM, Jacobs C, Kullberg BJ, Van der Meer JWM. LPS-induced cytokine production and expression of $\beta_{2}$-integrins and CD14 by peripheral blood mononuclear cells of patients with homozygous familial hypercholesterolemia. Atherosclerosis 1998;141:99-105.

18. Leirisalo-Repo M, Jaattela M, Gylling H, Miettinen TA, Repo H. Phagocyte function in familial hypercholesterolaemia: peripheral blood monocytes exposed to lipopolysaccharide show increased tumour necrosis factor production. Scand. J. Immunol. 1990;32:679685 .

19. de Bont N, Netea MG, Rovers C, Smilde TJ, Demacker PNM, Van der Meer JWM, Stalenhoef AFH. LPS-induced cytokine production and expression of LPS receptors by peripheral blood mononuclear cells of patients with familial hypercholesterolemia and the effect of HMG-CoA reductase inhibitors. Atherosclerosis 1998;139:147-152.

20. Esfahani M, Bigler RD, Alfieri JL, Lund-Katz S, Baum JD, Scerbo L. Cholesterol regulates the cell surface expression of glycophospholipid-anchored CD14 antigen on human monocytes. Biochim. Biophys. Acta 1993;1149:217-223.

21. Randomised trial of cholesterol lowering in 4444 patients with coronary heart disease: the Scandinavian Simvastatin Survival Study (4S). Lancet 1994;344:1383-1389.

22. Pahan K, Sheikh FG, Namboodiri AM, Singh I. Lovastatin and phenylacetate inhibit the induction of nitric oxide synthase and cytokines in rat primary astrocytes, microglia, and macrophages. $J$. Clin. Invest. 1997;100:2671-2679.

23. Terkeltaub R, Solan J, Barry MJ, Santoro D, Bokoch GM. Role of the mevalonate pathway of isoprenoid synthesis in IL-8 generation by activated monocytic cells. J. Leukoc. Biol. 1994;55:749-755.

24. Kim SY, Guijarro C, O'Donnell MP, Kasiske BL, Kim Y, Keane WF. Human mesangial cell production of monocyte chemoattractant protein-1: modulation by lovastatin. Kidney Int. 1995;48: 363-371.

25. Van-Zee KJ, Kohno T, Fischer E, Rock CS, Moldawer LL, Lowry SF. Tumor necrosis factor soluble receptors circulate during experimental and clinical inflammation and can protect against excessive tumor necrosis factor alpha in vitro and in vivo. Proc. Natl. Acad. Sci. USA 1992;89:4845-4849.

26. Demacker PN, Hijmans AG, Brenninkmeijer BJ, Jansen AP, van'tLaar A. Five methods for determining low-density lipoprotein cholesterol compared. Clin. Chem. 1984;30:1797-1800.

27. Friedewald WT, Levy RI, Fredrickson DS. Estimation of the concentration of low-density lipoprotein cholesterol in plasma, without use of the preparative ultracentrifuge. Clin. Chem. 1972;18: 499-502.

28. van Deuren M, van der Ven-Jongekrijg J, Keuter M, Demacker PNM, van der Meer JWM. Cytokine production in whole blood cultures. J. Int. Fed. Clin. Chem. 1993;5:216-221. 
29. Netea MG, Drenth JP, De-Bont N, Hijmans A, Keuter M, Dharmana E, Demacker PNM, Van der Meer JWM. A semi-quantitative reverse transcriptase polymerase chain reaction method for measurement of mRNA for TNF-alpha and IL-1 beta in whole blood cultures: its application in typhoid fever and exentric exercise. Cytokine 1996;8:739-744.

30. Drenth JP, Van-Uum SH, van-Deuren M, Pesman GJ, Van-derVen-Jongekrijg J, van-der-Meer JW. Endurance run increases circulating IL-6 and IL-1Ra but downregulates ex vivo TNF-alpha and IL-1 beta production. J. Appl. Physiol. 1995;79:1497-1503.

31. Li H, Freeman MW, Libby P. Regulation of smooth muscle cell scavenger receptor expression in vivo by atherogenic diets and in vitro by cytokines. J. Clin. Invest. 1995;95:122-133.

32. Libby P, Sukhova G, Lee RT, Galis ZS. Cytokines regulate vascular functions related to stability of the atherosclerotic plaque. $J$. Cardiovasc. Pharmacol. 1995;25(Suppl 2):S9-12.

33. Ross R. The pathogenesis of atherosclerosis: a perspective for the 1990s. Nature 1993;362:801-809.

34. Jack RS, Fan X, Bernheiden M, Rune G., Ehlers M, Weber A, Kirsch G, Mentel R, Furll B, Freudenberg M, Schmitz G, Stelter F, Schutt C. Lipopolysaccharide-binding protein is required to combat a murine gram-negative bacterial infection. Nature 1997;389: $742-745$.

35. Wurfel MM, Monks BG, Ingalls RR, Dedrick RL, Delude R, Zhou D, Lamping N, Schumann RR, Thieringer R, Fenton MJ, Wright $\mathrm{SD}$, Golenbock D. Targeted deletion of the lipopolysaccharide (LPS)-binding protein gene leads to profound suppression of LPS responses ex vivo, whereas in vivo responses remain intact. J. Exp. Med. 1997;186:2051-2056.
36. Pan HY, DeVault AR, Wang-Iverson D, Ivashkir BN, Swanson N, Sugerman A. Comparative pharmacokinetics and pharmacodynamics of pravastatin and lovastatin. J. Clin. Pharmacol. 1990;30: $1128-1135$.

37. Koga T, Shimada Y, Kuroda M, Tsujita Y, Hasegawa K, Yamazaki M. Tissue-selective inhibition of cholesterol synthesis in vivo by pravastatin sodium, a 3-hydroxy-3-methylglutaryl coenzyme A reductase inhibitor. Biochim. Biophys. Acta 1990;1045:115-120.

38. Endo A. Chemistry, biochemistry, and pharmacology of HMGCoA reductase inhibitors. Klin. Wochenschr. 1988;66:421-427.

39. Porreca E, Di-Febbo C, Barbacane RC, Panara MR, Cuccurullo F, Conti P. Effect of interleukin-1 receptor antagonist on vascular smooth muscle cell proliferation. Atherosclerosis 1993;99:71-78.

Address correspondence to:

Dr. Anton F.H. Stalenhoef

Department of Medicine (463)

Radboud University Medical Center

P.O.Box 9101

6500 HB Nijmegen

The Netherlands

Tel: +31-24-3618819

Fax: +31-24-3541734

E-mail: A.Stalenhoef@aig.umcn.nl

Received 20 December 2004/Accepted 27 July 2005 